\title{
The CPEB3 ribozyme modulates hippocampal-dependent memory
}

\author{
Authors \\ Claire C. Chen ${ }^{1}$, Joseph $\mathrm{Han}^{2}$, Carlene A. Chinn ${ }^{2}$, Xiang Li ${ }^{2 \dagger}$, Mehran Nikan ${ }^{3}$, Marie Myszka ${ }^{4}$, Liqi \\ Tong ${ }^{5}$, Timothy W. Bredy ${ }^{2 \dagger}$, Marcelo A. Wood ${ }^{2 *}$, Andrej Lupták ${ }^{1,4,6^{*}}$
}

\footnotetext{
Affiliations

${ }^{1}$ Department of Pharmaceutical Sciences, University of California-Irvine, Irvine, California 92697, United States.

${ }^{2}$ Department of Neurobiology and Behavior, Center for the Neurobiology of Learning and Memory, University of California-Irvine, Irvine, California 92697, United States.

${ }^{3}$ Ionis Pharmaceuticals, 2855 Gazelle Court, Carlsbad, CA 92010, USA.

${ }^{4}$ Department of Chemistry, University of California-Irvine, Irvine, California 92697, United States.

${ }^{5}$ Institute for Memory Impairments and Neurological Disorders, University of California-Irvine, Irvine, California 92697, United States.

${ }^{6}$ Department of Molecular Biology and Biochemistry, University of California-Irvine, Irvine, California 92697, United States

*Correspondence to: Andrej Lupták. Department of Pharmaceutical Sciences, University of California-Irvine, Irvine, California 92697, United States. aluptak@uci.edu. Marcelo A. Wood. Department of Neurobiology and Behavior, Center for the Neurobiology of Learning and Memory, University of California-Irvine, Irvine, California 92697, United States. mwood@uci.edu.

† Present address: Cognitive Neuroepigenetics Laboratory, Queensland Brain Institute, The University of Queensland, Brisbane, QLD 4072, Australia.
} 


\section{Abstract}

A self-cleaving ribozyme mapping to an intron of the cytoplasmic polyadenylation element binding protein 3 (CPEB3) gene has been suggested to play a role in human episodic memory, but the underlying mechanisms mediating this effect are not known. The ribozyme's selfscission half-life matches the time it takes an RNA polymerase to reach the immediate downstream exon, suggesting that the ribozyme-dependent intron cleavage is tuned to cotranscriptional splicing of the $C P E B 3$ mRNA. Here we report that the murine ribozyme modulates its own host mRNA maturation in both cultured cortical neurons and the hippocampus. Inhibition of the ribozyme using an antisense oligonucleotide leads to increased CPEB3 protein expression, which enhances polyadenylation and translation of localized plasticity-related target mRNAs, and subsequently strengthens hippocampal-dependent longterm memory. These findings reveal a previously unknown role for self-cleaving ribozyme activity in regulating experience-induced co-transcriptional and local translational processes required for learning and memory.

\section{Introduction}

Self-cleaving ribozymes are catalytic RNAs that accelerate site-specific scission of their backbone [1]. Several mammalian ribozymes have been identified [2-9], including a functionally-conserved sequence that maps to the second intron of the cytoplasmic polyadenylation element binding protein (CPEB3) gene $[4,10,11]$ (Fig 1A). The CPEB3 ribozyme shares its secondary structure and catalytic mechanism with the hepatitis delta virus (HDV) ribozymes [10, 12]. HDV-like ribozymes are widespread among genomes of eukaryotes [13-16] and their biological roles include processing of rolling-circle transcripts during HDV replication [2, 3], 5'-cleavage of retrotransposons [14-16], and in one bacterial example, potentially metabolite-dependent regulation of gene expression [17]. However, the 
function of the mammalian ribozyme is unknown. In humans, a single nucleotide polymorphism (SNP) at the ribozyme cleavage site leads to a 3-fold higher rate of in vitro self-scission, which correlates with poorer performance in an episodic memory task $[4,18]$ and suggests that the ribozyme activity might play a role in memory formation.

CPEBs are RNA-binding proteins that modulate polyadenylation-induced mRNA translation, which is essential for the persistence of memory [19]. CPEBs have been found in several invertebrate and vertebrate genomes, and four $C P E B$ genes $(C P E B 1-4)$ have been identified in mammals [20-24]. All CPEB proteins have two RNA recognition domains (RRM motifs) and a ZZ-type zinc finger domain in the C-terminal region, but differ in their Nterminal domains [25-27]. Aplysia CPEB (ApCPEB), Drosophila Orb2, and mouse CPEB3 have two distinct functional conformations that correspond to soluble monomers and amyloidogenic oligomers, and have been implicated in maintenance of long-term facilitation (LTF) in Aplysia and long-term memory in both Drosophila and mice [28-34]. In Drosophila, inhibition of amyloid-like oligomerization of Orb2 impairs the persistence of long-lasting memory, and deletion of prion-like domain of Orb2 disrupts long-term courtship memory [32, 35]. The aggregated form of CPEB3, which is inhibited by SUMOylation, can mediate target mRNA translation at activated synapses [36].

Following synaptic stimulation CPEB3 interacts with actin cytoskeleton, with a positive feedback loop of CPEB3/actin regulating remodeling of synaptic structure and connections $[37,38]$. Studies of CPEB3 in memory formation revealed that the local protein synthesis and long-term memory storage are regulated by the prion-like CPEB3 aggregates (the aggregation of CPEB3 is thought to strengthen synaptic plasticity in the hippocampus); $C P E B 3$ conditional knockout mice display impairments in memory consolidation, object 
placement recognition, and long-term memory maintenance [31]. On the other hand, global CPEB3 knockout mice display enhanced spatial memory consolidation in the Morris water maze and exhibit elevated short-term fear during the acquisition and extinction of contextual fear memory [39].

The CPEB3 protein is thus well established as a modulator of memory formation and learning, but the function of the CPEB3 ribozyme has not been tested. Given that the selfscission of intronic ribozymes is inversely correlated with splicing efficiency of the harboring pre-mRNA [40], we hypothesized that inhibition of the CPEB3 ribozyme co-transcriptional self-self-cleavage can alter $C P E B 3$ mRNA splicing and increase the expression of full-length mRNA and CPEB3 protein, leading to polyadenylation of its target mRNAs and an enhancement in the consolidation of hippocampal-dependent memory.

\section{Results}

CPEB3 mRNA expression and ribozyme activity are upregulated in response to

\section{neuronal stimulation}

To test this hypothesis, we began by measuring the co-transcriptional self-scission of the murine variant of the ribozyme in vitro and found a half-life $\left(\mathrm{t}_{1 / 2}\right)$ of $\sim 2$ minutes (Fig 1B and Table S1), which is similar to previously measured chimp and fast-reacting human variants of the ribozyme [41]. Because the distance from the ribozyme to the $3^{\text {rd }}$ exon in the CPEB3 gene is about $10 \mathrm{~kb}$ and the RNA polymerase II (RNAPII) transcription rate of long mammalian genes is estimated to be $\sim 3.5-4.1 \mathrm{knt} / \mathrm{min}$ [42], RNAPII would take about $2.5-3$ 
minutes to reach the $3^{\text {rd }}$ exon and mark it for splicing. This result suggested that the ribozyme activity is tuned to the co-transcriptional processing of the CPEB3 pre-mRNA.

The neuronal activity-dependent gene regulation is essential for synaptic plasticity [43]. To investigate the effect of the CPEB3 ribozyme on CPEB3 mRNA expression and measure its effect on maturation and protein levels, we stimulated primary cortical neurons by glutamate or potassium chloride $(\mathrm{KCl})$. First, $C P E B 3$ mRNA levels were measured using primers that specifically amplified exon-exon splice junctions (Exons 2-3, 3-6, 6-9; Fig 1A). We found that membrane depolarization by $\mathrm{KCl}$ led to an up-regulation of $C P E B 3$ mRNA 2 hours post stimulation, compared with non-stimulated cultures (Fig 1C). To examine CPEB3 ribozyme activity, total ribozyme and uncleaved ribozyme levels were measured by qRTPCR, which showed that ribozyme expression is elevated at 1 hour following $\mathrm{KCl}$ treatment (Fig 1D). Similarly, glutamate stimulation both increased the expression of spliced exons by 2-3 fold at 2 hours, with a decrease observed at later time points (Fig 1E), and increased ribozyme expression correlated with CPEB3 mRNA expression (Fig 1F). This finding is supported by previous studies showing that synaptic stimulation by glutamate leads to an increase in CPEB3 protein expression in hippocampal neurons [31] and that treatment with kainate likewise induces CPEB3 expression in the hippocampus [21]. The cleaved fraction of the ribozyme was greatest at the highest point of CPEB3 mRNA expression, suggesting efficient co-transcriptional self-scission. Together, these data (i) indicate that the self-cleaving CPEB3 ribozyme is expressed, and potentially activated, in response to neuronal activity, and (ii) suggest that CPEB3 ribozyme cis-regulates the maturation of CPEB3 mRNA.

CPEB3 mRNA and protein levels increase in primary neuronal cultures treated with ribozyme inhibitor 

expression, we hypothesized that regulation of the ribozyme may modulate CPEB3 mRNA splicing. To test this hypothesis, we inhibited the ribozyme using antisense oligonucleotides

To study the effect of the CPEB3 ribozyme on CPEB3 mRNA expression, neuronal cultures were pretreated with either an ASO or a non-targeting control oligonucleotide, followed by $\mathrm{KCl}$ stimulation. In the absence of $\mathrm{ASO}, \mathrm{KCl}$ induced a rapid and robust increase in ribozyme levels compared to cultures containing scrambled ASO, and this effect was suppressed in the presence of ASO, suggesting that the ribozyme is blocked by the ASO (S1A Fig). At an early time point (2 hours post- $\mathrm{KCl}$ induction), the ASO-containing culture displayed an increase of spliced mRNA (Figs 2C, S1 B and C), suggesting that the ASO prevents CPEB3 ribozyme from cleaving the intron co-transcriptionally and promotes mRNA maturation. At 24 hours post- $\mathrm{KCl}$ induction, we observed no significant difference in $\mathrm{CPEB} 3$ ribozyme expression among groups (S1D Fig). Likewise, the level of CPEB3 mRNA exons 2-3 returned to the basal level (S1E Fig), while exons 3-6 remained slightly elevated in the ASO-treatment groups (S1F Fig). The mRNA expression of CPEB3 exons 6-9 remained 
stable over time and was not affected by ASO treatment or $\mathrm{KCl}$ stimulation (S1G Fig). Taken together, these data suggest that the CPEB3 ribozyme modulates the production of the fulllength $C P E B 3$ mRNA.

To evaluate whether the ASO specifically targets CPEB3 ribozyme or modulates intron levels in general, we measured the levels of the $4^{\text {th }}$ CPEB3 intron, which does not harbor a self-cleaving ribozyme. No significant difference in the $4^{\text {th }}$ intron expression between groups was observed, demonstrating that the ASO does not have a broad non-specific effect on the stability of other introns (Fig S2H). Furthermore, to assess whether the ASO induces cytotoxicity in vitro, neuronal cultures were treated with either ASO or scrambled ASO. Cell viability was measured with an XTT assay, revealing no difference in either ASO- or scrambled ASO-treated cells, compared to untreated cells. These data suggest that the ASOs used in this study did not induce cytotoxic effects in cultured neurons (S1I Fig).

We next determined whether inhibition of CPEB3 ribozyme regulates CPEB3 protein expression. Treatment with the ribozyme ASO resulted in a significant increase in CPEB3 protein levels in both the basal state and under $\mathrm{KCl}$-stimulated conditions, indicating a coordination of activity-dependent transcription and translation upon inhibition of CPEB3 ribozyme activity (Fig 2D).

\section{Ribozyme inhibition leads to increased expression of plasticity-related proteins}

In Aplysia sensory-motor neuron co-culture, application of repeated pulses of serotonin (5-HT) induces ApCPEB protein expression at the stimulated synapses and LTF, which is a form of learning-related synaptic plasticity that is widely studied in Aplysia [20, 29]. In murine primary hippocampal neurons, the level of CPEB3 protein expression is 
positively regulated by neuronal activity [31] and plays dual roles in regulating mRNA translation $[37,46]$ whereby a post-translational modification of CPEB3 can convert it from a repressor to an activator: a monoubiquitination by Neuralized1 leads to activation of CPEB3, which promotes subsequent polyadenylation and translation of GluA1 and GluA2 [47]. Previous studies have also demonstrated the role of CPEB3 in the translational regulation of a number of plasticity-related proteins (PRPs), including AMPA-type glutamate receptors (AMPARs), NMDA receptor (NMDAR), and postsynaptic density protein 95 (PSD-95) [26, 31, 39, 48]. As an RNA binding protein, CPEB3 has been shown to bind to 3' UTR of GluA1, GluA2, and PSD-95 mRNAs and to regulate their polyadenylation and translation $[26,31,39$, 47].

To test whether inhibition of CPEB3 ribozyme modulates expression of PRPs, we measured the protein levels. We found that under $\mathrm{KCl}$-induced depolarizing conditions, treatment with the CPEB3 ribozyme ASO resulted in a significant increase in GluA1 and PSD-95 protein expression, whereas GluA2 levels remained unchanged (S2A and S2B Fig). Likewise, ASO treatment led to an up-regulation of NR2B protein, one of the NMDAR subunits (S2C and S2D Fig). These results suggest that CPEB3 ribozyme activity affects several downstream processes, particularly mRNA maturation and translation, as well as the expression of PRPs, including the translation of AMPAR and NMDAR mRNAs.

\section{CPEB3 ribozyme ASO leads to an increase of CPEB3 mRNA and polyadenylation of}

\section{PRPs in the CA1 hippocampus}

To investigate whether the CPEB3 ribozyme exhibits similar effects in regulating genes related to synaptic plasticity in vivo, mice were stereotaxically infused with either ribozyme ASO, scrambled ASO, or vehicle into the CA1 region of the dorsal hippocampus, a 
major brain region involved in memory consolidation and persistence (Fig 3A). Infusion of ASO targeting the CPEB3 ribozyme significantly reduced ribozyme levels detected by RTqPCR in the dorsal hippocampus (S3A Fig). We found that administration of ASO led to an

To further delineate whether the CPEB3 ribozyme activity results in polyadenylation of its target mRNAs, $3^{\prime}$ rapid amplification of cDNA ends ( $\left.3^{\prime} \mathrm{RACE}\right)$ was performed to examine the $3^{\prime}$ termini of several mRNAs. We found that ribozyme ASO administration led to increased GluA1, GluA2, and PSD-95 mRNA polyadenylation in the mouse dorsal hippocampus (Fig 3C). These data support a model wherein the inhibition of the CPEB3 ribozyme leads to increased polyadenylation of existing AMPARs and PSD-95 mRNAs, and suggests a role in post-transcriptional regulation and $3^{\prime}$ mRNA processing. 
To assess whether inhibition of the CPEB3 ribozyme improves memory formation, we tested it with respect to long-term memory using the object location memory (OLM) task (Fig 4A). The OLM task has been widely used to study hippocampal-dependent spatial memory. The task is based on an animal's innate preference for novelty and its capability for discriminating spatial relationships between novel and familiar locations [49]. During a testing session, mice retrieve the memory that encoded for the objects they were exposed to in the training session. We infused mice bilaterally into the CA1 dorsal hippocampus with the CPEB3 ribozyme ASO, scrambled ASO, or vehicle 48 hours prior to OLM training. The CPEB3 ribozyme ASO group showed a significant increase in discrimination index (DI) between training and testing compared to control groups, suggesting that these mice experienced a robust enhancement of novel object exploration (Fig 4B). We observed no significant difference in training DI $(P>0.05)$, indicating that mice exhibit no preference for either object (Fig 4B). Likewise, during training and testing sessions, ASO-infused mice and control mice displayed similar total exploration time, demonstrating that both groups of mice have similar exploitative behavior (Fig 4C). These results provide strong evidence that CPEB3 is critical for long-term memory, and that the CPEB3 ribozyme activity is anticorrelated with the formation of long-term memory.

\section{CPEB3 ribozyme ASO leads to an upregulation in protein expression of CPEB3 and}

\section{PRPs during memory consolidation}

Learning-induced changes in gene expression and protein synthesis are essential for memory formation and consolidation [50]. To determine whether upregulation of CPEB3 mRNA by the ribozyme ASO leads to a change in expression of the CPEB3 protein and its downstream targets, we analyzed the dorsal hippocampal homogenates and synaptosomal fractions. Administration of CPEB3 ribozyme ASO led to a significant increase of CPEB3 
protein expression in the CA1 hippocampal homogenates and crude synaptosomes 1 hour

\section{Discussion}

Self-cleaving ribozymes are broadly distributed small functional RNAs that catalyze a site-specific scission of their backbone [1]. The HDV family of these ribozymes acts during rolling circle replication of the HDV RNA genome and in processing of retrotransposons [2, 3, 14-16], but given their broad distribution in nature, their biological roles are largely unexplored. Mammals harbor several self-cleaving ribozymes-all without known biological functions [4-9]. One of these ribozymes, the HDV-like CPEB3 ribozyme, maps to the second intron of the $C P E B 3$ gene and its in vitro activity (Figs 1A and 1B) suggested that its rate of self-scission may be tuned to disrupt the intron at a rate that is similar to the production speed of the downstream intronic sequence ahead of the next exon. Previous work on synthetic ribozymes placed within introns of mammalian genes showed that splicing of the surrounding exons is sensitive to the continuity of the intron: fast ribozymes caused efficient self-scission of the intron, leading to unspliced mRNA and resulting in lower protein expression, whereas 
slow ribozymes had no effect on mRNA splicing and subsequent protein expression [40].

Inspired by this work, we investigated how the intronic ribozyme affects the $C P E B 3$ mRNA maturation and translation, and its effect on memory formation in mice.

Modifications of synaptic strength are thought to underlie learning and memory in the brain. Studies in hippocampal slices revealed local translation in dendrites following induction of LTP [51]. Cytoplasmic polyadenylation-induced translation is one of the key steps for regulating protein synthesis and neuroplasticity [22, 46, 52]. One of the proteins involved in regulation of cytoplasmic polyadenylation of mRNAs is CPEB3. Recent studies have shown that CPEB3 regulates mRNA translation of several PRPs at synapses, where it is essential for synaptic strength $[26,31,47]$. Previous reports have shown that CPEB3 regulates GluA1 and GluA2 polyadenylation: CPEB3 conditional knockout mice fail to elongate the poly(A) tail of GluA1 and GluA2 mRNA after Morris water maze training, and overexpression of CPEB3 changes the length of the GluA1 and GluA2 mRNA poly(A) tail [31]. Even though translational control by regulation of CPEB3 has been demonstrated to contribute to the hippocampal-dependent learning and memory [47], one unaddressed question is whether the CPEB3 expression is modulated by the CPEB3 ribozyme. In mammals, the coordination of pre-mRNA processing and transcription can affect its gene expression [53]. Recent measurement of co-transcriptional splicing events in mammalian cells using long-read sequencing and Precision Run-On sequencing (PRO-seq) approaches demonstrated that co-transcriptional splicing efficiency impacts productive gene output [54]. The temporal and spatial window shows that the splicing and transcription machinery are tightly coupled. In agreement with this co-transcriptional splicing model, our study shows that inhibition of the intronic $\mathrm{CPEB} 3$ ribozyme leads to an increase in $C P E B 3 \mathrm{mRNA}$ and protein 
levels in primary cortical neurons and the dorsal hippocampus upon synaptic stimulation, and leading to changes in polyadenylation of target mRNAs of the CPEB3 protein.

Activity-dependent synaptic changes are governed by AMPAR trafficking, and AMPARs are mobilized to the post-synaptic surface membrane in response to neuronal activity in a dynamic process [55]. Our data demonstrate that the activation of CPEB3 by

ASOs have been used in many studies to inhibit specific mRNAs. A notable example is an FDA-approved ASO that modulates co-transcriptional splicing of the SMN2 mRNA [45]. Our works shows that an ASO designed to bind the substrate strand of an endogenous self-cleaving ribozyme located in an intron increases the expression of the fully spliced mRNA that harbors the ribozyme. Interestingly, experiments with inhibitory ASO yielded lower the ribozyme levels than control experiments, suggesting that the ASO directs degradation of the target sequence; however, this degradation must occur on a timescale that is longer than the splicing of the mRNA, because we consistently see higher mRNA levels when the ribozyme is inhibited. Further studies will be necessary to delineate the full mechanism of action of anti-ribozyme ASOs. Given that three endogenous mammalian self- 
cleaving ribozymes map to introns [4, 6, 7], we anticipate that application of ASOs will help decipher their effect on their harboring mRNAs and establish their biological roles.

In summary, we have delineated an important step in molecular mechanisms underlying a unique role for the CPEB3 ribozyme in post-transcriptional maturation of CPEB3 mRNA and its subsequent translation in mouse CA1 hippocampus. Inhibition of the CPEB3 ribozyme by ASO and OLM training induce activity-dependent upregulation of CPEB3 and local production of PRPs. These molecular changes are critical for establishing persistent changes in synaptic plasticity that are required for long-term memory, and represent a biological role for self-cleaving ribozymes in the brain. More broadly, our study demonstrates a novel biological role for self-cleaving ribozymes and the first example of their function in mammals.

\section{Materials and Methods}

\section{Primary cortical neuronal culture}

Pregnant female C57BL/6 mice (The Jackson Laboratory) were euthanized at E18, and embryos were collected into an ice-cold Neurobasal medium (Thermo Fisher Scientific). Embryonic cortices were dissected, meninges were removed, and tissues were minced. Cells were mechanically dissociated, passed through a $40-\mu \mathrm{m}$ cell strainer, counted, and plated at a density of $0.5 \times 10^{6}$ cells per well in six-well plates coated with poly-D-lysine (SigmaAldrich). Neuronal cultures were maintained at $37{ }^{\circ} \mathrm{C}$ with $5 \% \mathrm{CO}_{2}$, and grown in Neurobasal medium containing 2\% B27 supplement (Thermo Fisher Scientific), 1\% penicillin/streptomycin (Thermo Fisher Scientific), and $2 \mathrm{mM} \mathrm{L-Glutamine} \mathrm{(Thermo} \mathrm{Fisher}$ Scientific) for 7-10 days in vitro (DIV), with $50 \%$ of the medium being replaced every 3 days. All experimental procedures were performed according to the National Institutes of 
Health Guide for the Care and Use of Laboratory Animals and approved by the Institutional Animal Care and Use Committee of the University of California, Irvine.

Mice

C57BL/6J mice (8-10 weeks old, The Jackson Laboratory) were housed in a 12-h light/dark cycle and had free access to water and food. All experiments were conducted

\section{Measurement of co-transcriptional self-scission of the CPEB3 ribozyme}

Transcription reactions were set up in a $5-\mu \mathrm{L}$ volume and incubated for 10 minutes at $25^{\circ} \mathrm{C}$, as described previously [17]. The reactions contained: $1 \mu \mathrm{L}$ of $5 \mathrm{x}$ transcription buffer (10 mM spermidine, $50 \mathrm{mM}$ dithiothreitol, $120 \mathrm{mM}$ Tris chloride buffer, $\mathrm{pH} 7.5$, and $0.05 \%$ Triton X-100), $1 \mu \mathrm{L}$ of $5 \mathrm{x}$ ribonucleoside triphosphates (final concentration of $6.8 \mathrm{mM}$ ), $1 \mu \mathrm{L}$ of $5 \mathrm{mM} \mathrm{Mg}^{2+}, 1 \mu \mathrm{L}$ DNA amplified by PCR to about $1 \mu \mathrm{M}$ final concentration, $0.5 \mu \mathrm{L}$ of $100 \%$ DMSO, $0.15 \mu \mathrm{L}$ of water, $0.1 \mu \mathrm{L}$ of murine RNase inhibitor (40,000 units/mL, New England Biolabs), $0.125 \mu \mathrm{L}$ of $\mathrm{T} 7$ polymerase, and $0.125 \mu \mathrm{L}\left[\alpha_{-}{ }^{32} \mathrm{P}\right] \mathrm{ATP}$. To prevent initiation of new transcription, the reactions were diluted into $100 \mu \mathrm{L}$ of physiological-like buffer solution at $37^{\circ} \mathrm{C}$. The solution consisted of $2 \mathrm{mM} \mathrm{Mg}^{2+}$ (to promote ribozyme selfscission), $140 \mathrm{mM} \mathrm{KCl}, 10 \mathrm{mM} \mathrm{NaCl}$, and $50 \mathrm{mM}$ Tris chloride buffer (pH 7.5). The 100- $\mu \mathrm{L}$ solution was then held at $37^{\circ} \mathrm{C}$ for the reminder of the experiment while aliquots were withdrawn at various time points. An equal volume of $4 \mathrm{mM}$ EDTA/7 $\mathrm{M}$ urea stopping solution was added to each aliquot collected. Aliquots were resolved using denaturing polyacrylamide gel electrophoresis (PAGE, 7.5\% polyacrylamide, $7 \mathrm{M}$ urea) at $20 \mathrm{~W}$. The 
PAGE gel was exposed to a phosphosimage screen for $\sim 2$ hours and analyzed using a

\section{Antisense oligonucleotides (ASOs)}

ASOs used in this study are 20 nucleotides in length and are chemically modified with 2'-O-methoxyethyl (MOE, underlined) and 2'-4' constrained ethyl (cEt, bold) [57]. All internucleoside linkages are modified with phosphorothioate linkages to improve nuclease resistance. ASOs were solubilized in sterile phosphate-buffered saline (PBS). The sequences of the ASOs are as follows (all cytosine nucleobases are 5-methyl substituted):

Scrambled control ASO: 5'-CTTCCCTGAAGGTTCCTCC-3';

CPEB3 ribozyme ASO: 5'-TGTGGCCCCCTGTTATCCTC-3'.

\section{Neuronal stimulation}

Neurons were treated with ASO or scrambled ASO $(1 \mu \mathrm{M})$ for 18 hours prior to neuronal stimulation. To study activity-dependent gene regulation, neuronal cultures were treated with vehicle, $5 \mu \mathrm{M}$ glutamate (10 minutes), or $35 \mathrm{mM} \mathrm{KCl} \mathrm{(5} \mathrm{minutes).} \mathrm{After}$ 
stimulation, cultures were washed with Hanks' buffered salt solution (HBSS, Thermo Fisher Scientific), and then replaced with fresh medium.

\section{Quantitative RT-PCR analysis}

Total RNA was isolated from primary cortical neurons or mouse hippocampus using TRI reagent (Sigma-Aldrich) according to the manufacturer's protocol. RNA concentration was measured using a NanoDrop ND-1000 spectrophotometer (Thermo Fisher Scientific). Total RNA was reverse transcribed using random decamers and M-MLV reverse transcriptase (Promega)/Superscript II RNase $\mathrm{H}$ reverse transcriptase (Thermo Fisher Scientific). Quantitative RT-PCR was performed on a BioRad CFX Connect system using iTaq Universal SYBR Green Supermix (BioRad). Designed primers were acquired from Integrated DNA Technologies and provided in Table S2. Desired amplicons were verified by melting curve analysis and followed by gel electrophoresis. The starting quantity of DNA from each sample was determined by interpolation of the threshold cycle (CT) from a standard curve of each primer set. Relative gene expression levels were normalized to the endogenous gene GAPDH.

\section{Immunoblotting}

Primary cortical neurons or mouse hippocampal tissues were lysed in RIPA lysis buffer with protease inhibitor (Santa Cruz Biotechnology). Crude synaptosomal fractions were prepared as previously described [58]. Protein concentrations were measured using bicinchoninic acid (BCA) protein assay (Thermo Fisher Scientific). Ten to $30 \mu \mathrm{g}$ of protein samples were loaded on $10 \%$ sodium dodecyl sulfate polyacrylamide (SDS-PAGE) gels and separated by electrophoresis. Gels were electro-transferred onto polyvinylidene fluoride (PVDF) membranes using a semi-dry transfer system (BioRad). Membranes were either 
blocked with $5 \%$ nonfat milk or $5 \%$ bovine serum albumin (BSA) in Tris-buffered saline/Tween $20(0.1 \%$ [vol/vol]) (TBST) for 1 hour at room temperature. Membranes were

\section{Stereotaxic surgeries}

C57/BL6J mice (8-10 weeks old, Jackson Laboratory), housed under standard conditions with light-control (12-h light/12-h dark cycles), were anaesthetized with an isoflurane (1-3\%)/oxygen vapor mixture. Mice were infused bilaterally to the CA1 region of 
the dorsal hippocampus with ribozyme ASO, scrambled ASO diluted in sterile PBS, or

vehicle. The following coordinates were used, relative to bregma: medial-lateral (ML), \pm 1.5 $\mathrm{mm}$; anterior-posterior (AP), $-2.0 \mathrm{~mm}$; dorsal-ventral (DV), $-1.5 \mathrm{~mm}$. ASOs or vehicle (1 $\mathrm{nmol} / \mu \mathrm{L}$ ) were infused bilaterally at a rate of $0.1 \mu \mathrm{L} / \mathrm{min}$ using a Neuros Hamilton syringe (Hamilton company) with a syringe pump (Harvard Apparatus). The injectors were left in place for 2 minutes to allow diffusion, and then were slowly removed at a rate of $0.1 \mathrm{~mm}$ per

\section{Object location memory (OLM) tasks}

The OLM was performed to assess hippocampus-dependent memory, as previously described [49]. Briefly, naïve C57/BL6J mice (8-12 weeks old; $\mathrm{n}=10-12$ /group; ribozyme ASO, scrambled ASO) were trained and tested. Prior to training, mice were handled 1-2 minutes for 5 days and then habituated to the experimental apparatus for 5 minutes on 6 consecutive days in the absence of objects. During training, mice were placed into the apparatus with two identical objects and allowed to explore the objects for 10 minutes. Twenty-four hours after training, mice were exposed to the same arena, and long-term memory was tested for 5 minutes, with the two identical objects present, one of which was placed in a novel location. For all experiments, objects and locations were counterbalanced across all groups to reduce bias. Videos of training and testing sessions were analyzed for discrimination index (DI) and total exploration time of objects. The videos were scored by observers blind to the treatment. The exploration of the objects was scored when the mouse's snout was oriented toward the object within a distance of $1 \mathrm{~cm}$ or when the nose was touching the object. The relative exploration time was calculated as a discrimination index $\left(\mathrm{DI}=\left(t_{\mathrm{novel}}\right.\right.$ 
$\left.\left.-t_{\text {familiar }}\right) /\left(t_{\text {novel }}+t_{\text {familiar }}\right) \times 100 \%\right)$. Mice that demonstrated a location or an object preference during the training trial (DI $> \pm 20)$ were removed from analysis.

\section{Statistical analysis}

Data are presented as means \pm SEM. Statistical analyses were performed using GraphPad Prism (GraphPad Prism Software). Statistical differences were determined using two-tailed Welch's $t$ test when comparing between 2 independent groups, and one-way ANOVA with Sidak's post hoc tests when comparing across 3 or more independent groups. 
bioRxiv preprint doi: https://doi.org/10.1101/2021.01.23.426448; this version posted May 5, 2021. The copyright holder for this preprint (which was not certified by peer review) is the author/funder, who has granted bioRxiv a license to display the preprint in perpetuity. It is made available under aCC-BY-NC-ND 4.0 International license. was considered significant. 
bioRxiv preprint doi: https://doi.org/10.1101/2021.01.23.426448; this version posted May 5, 2021. The copyright holder for this preprint (which was not certified by peer review) is the author/funder, who has granted bioRxiv a license to display the preprint in perpetuity. It is made available under aCC-BY-NC-ND 4.0 International license.

\section{References}

1. Jimenez RM, Polanco JA, Luptak A. Chemistry and Biology of Self-Cleaving Ribozymes. Trends Biochem Sci. 2015;40(11):648-61. doi: 10.1016/j.tibs.2015.09.001. PubMed PMID: 26481500; PubMed Central PMCID: PMCPMC4630146.

2. Sharmeen L, Kuo MY, Dinter-Gottlieb G, Taylor J. Antigenomic RNA of human hepatitis delta virus can undergo self-cleavage. J Virol. 1988;62(8):2674-9. PubMed PMID: 2455816; PubMed Central PMCID: PMCPMC253699.

3. Wu HN, Lin YJ, Lin FP, Makino S, Chang MF, Lai MMC. Human Hepatitis-Delta Virus-Rna Subfragments Contain an Autocleavage Activity. P Natl Acad Sci USA. 1989;86(6):1831-5. doi: DOI 10.1073/pnas.86.6.1831. PubMed PMID: WOS:A1989T788900019.

4. Salehi-Ashtiani K, Luptak A, Litovchick A, Szostak JW. A genomewide search for ribozymes reveals an HDV-like sequence in the human CPEB3 gene. Science. 2006;313(5794):1788-92. doi: 10.1126/science.1129308. PubMed PMID: 16990549.

5. Martick M, Horan LH, Noller HF, Scott WG. A discontinuous hammerhead ribozyme embedded in a mammalian messenger RNA. Nature. 2008;454(7206):899-U57. doi: 10.1038/nature07117. PubMed PMID: WOS:000258398600039.

6. de la Pena M, Garcia-Robles I. Intronic hammerhead ribozymes are ultraconserved in the human genome. Embo Rep. 2010;11(9):711-6. doi: 10.1038/embor.2010.100. PubMed PMID: WOS:000281467200016.

7. Perreault J, Weinberg Z, Roth A, Popescu O, Chartrand P, Ferbeyre G, et al. Identification of Hammerhead Ribozymes in All Domains of Life Reveals Novel Structural Variations. Plos Comput Biol. 2011;7(5). doi: ARTN e1002031 10.1371/journal.pcbi.1002031. PubMed PMID: WOS:000291015800014.

8. Chen Y, Qi F, Gao F, Cao HF, Xu DY, Salehi-Ashtiani K, et al. Hovlinc is a recently evolved class of ribozyme found in human lncRNA. Nat Chem Biol. 2021. doi: 10.1038/s41589-02100763-0. PubMed PMID: WOS:000631491100002.

9. Hernandez AJ, Zovoilis A, Cifuentes-Rojas C, Han L, Bujisic B, Lee JT. B2 and ALU retrotransposons are self-cleaving ribozymes whose activity is enhanced by EZH2. P Natl Acad Sci USA. 2020;117(1):415-25. doi: 10.1073/pnas.1917190117. PubMed PMID: WOS:000506001200062.

10. Webb CH, Luptak A. HDV-like self-cleaving ribozymes. RNA Biol. 2011;8(5):719-27. doi: 10.4161/rna.8.5.16226. PubMed PMID: 21734469; PubMed Central PMCID: PMCPMC3256349.

11. Bendixsen DP, Pollock TB, Peri G, Hayden EJ. Experimental Resurrection of Ancestral Mammalian CPEB3 Ribozymes Reveals Deep Functional Conservation. Molecular Biology and Evolution. 2021. doi: 10.1093/molbev/msab074.

12. Skilandat M, Rowinska-Zyrek M, Sigel RK. Secondary structure confirmation and localization of Mg2+ ions in the mammalian CPEB3 ribozyme. RNA. 2016;22(5):750-63. doi:

10.1261/rna.053843.115. PubMed PMID: 26966151; PubMed Central PMCID: PMCPMC4836649.

13. Webb CH, Riccitelli NJ, Ruminski DJ, Luptak A. Widespread occurrence of self-cleaving ribozymes. Science. 2009;326(5955):953. doi: 10.1126/science.1178084. PubMed PMID: 19965505; PubMed Central PMCID: PMCPMC3159031.

14. Ruminski DJ, Webb CH, Riccitelli NJ, Luptak A. Processing and translation initiation of nonlong terminal repeat retrotransposons by hepatitis delta virus (HDV)-like self-cleaving ribozymes. J Biol Chem. 2011;286(48):41286-95. doi: 10.1074/jbc.M111.297283. PubMed PMID: 21994949; PubMed Central PMCID: PMCPMC3308841. 
15. Eickbush DG, Eickbush TH. R2 Retrotransposons Encode a Self-Cleaving Ribozyme for Processing from an rRNA Cotranscript. Molecular and Cellular Biology. 2010;30(13):3142-50. doi: 10.1128/Mcb.00300-10. PubMed PMID: WOS:000278626100001.

16. Sanchez-Luque FJ, Lopez MC, Macias F, Alonso C, Thomas MC. Identification of an hepatitis delta virus-like ribozyme at the mRNA 5 '-end of the L1Tc retrotransposon from Trypanosoma cruzi. Nucleic Acids Research. 2011;39(18):8065-77. doi: 10.1093/nar/gkr478. PubMed PMID: WOS:000295687700023.

17. Passalacqua LFM, Jimenez RM, Fong JY, Luptak A. Allosteric Modulation of the Faecalibacterium prausnitzii Hepatitis Delta Virus-like Ribozyme by Glucosamine 6-Phosphate: The Substrate of the Adjacent Gene Product. Biochemistry-Us. 2017;56(45):6006-14. doi: 10.1021/acs.biochem.7b00879. PubMed PMID: 29045794; PubMed Central PMCID: PMCPMC5775185.

18. Vogler C, Spalek K, Aerni A, Demougin P, Muller A, Huynh KD, et al. CPEB3 is associated with human episodic memory. Front Behav Neurosci. 2009;3:4. doi: 10.3389/neuro.08.004.2009. PubMed PMID: 19503753; PubMed Central PMCID: PMCPMC2691156.

19. Huang YS, Carson JH, Barbarese E, Richter JD. Facilitation of dendritic mRNA transport by CPEB. Genes Dev. 2003;17(5):638-53. doi: 10.1101/gad.1053003. PubMed PMID: 12629046; PubMed Central PMCID: PMCPMC196011.

20. Si K, Giustetto M, Etkin A, Hsu R, Janisiewicz AM, Miniaci MC, et al. A neuronal isoform of CPEB regulates local protein synthesis and stabilizes synapse-specific long-term facilitation in aplysia. Cell. 2003;115(7):893-904. doi: 10.1016/s0092-8674(03)01021-3. PubMed PMID: 14697206.

21. Theis M, Si K, Kandel ER. Two previously undescribed members of the mouse CPEB family of genes and their inducible expression in the principal cell layers of the hippocampus. Proc Natl Acad Sci U S A. 2003;100(16):9602-7. doi: 10.1073/pnas.1133424100. PubMed PMID: 12871996; PubMed Central PMCID: PMCPMC170964.

22. Richter JD. CPEB: a life in translation. Trends Biochem Sci. 2007;32(6):279-85. doi: 10.1016/j.tibs.2007.04.004. PubMed PMID: 17481902.

23. Afroz T, Skrisovska L, Belloc E, Guillen-Boixet J, Mendez R, Allain FHT. A fly trap mechanism provides sequence-specific RNA recognition by CPEB proteins. Gene Dev. 2014;28(13):1498-514. doi: 10.1101/gad.241133.114. PubMed PMID: WOS:000338816000010.

24. Merkel DJ, Wells SB, Hilburn BC, Elazzouzi F, Alvarado GCP, Lee BM. The C-Terminal Region of Cytoplasmic Polyadenylation Element Binding Protein Is a ZZ Domain with Potential for Protein-Protein Interactions. Journal of Molecular Biology. 2013;425(11):2015-26. doi: 10.1016/j.jmb.2013.03.009. PubMed PMID: WOS:000320419300012.

25. Hake LE, Richter JD. CPEB is a specificity factor that mediates cytoplasmic polyadenylation during Xenopus oocyte maturation. Cell. 1994;79(4):617-27. PubMed PMID: 7954828.

26. Huang YS, Kan MC, Lin CL, Richter JD. CPEB3 and CPEB4 in neurons: analysis of RNAbinding specificity and translational control of AMPA receptor GluR2 mRNA. Embo J. 2006;25(20):4865-76. doi: 10.1038/sj.emboj.7601322. PubMed PMID: 17024188; PubMed Central PMCID: PMCPMC1618119.

27. Ivshina M, Lasko P, Richter JD. Cytoplasmic polyadenylation element binding proteins in development, health, and disease. Annu Rev Cell Dev Biol. 2014;30:393-415. doi: 10.1146/annurev-cellbio-101011-155831. PubMed PMID: 25068488.

28. Miniaci MC, Kim JH, Puthanveettil SV, Si K, Zhu H, Kandel ER, et al. Sustained CPEBdependent local protein synthesis is required to stabilize synaptic growth for persistence of longterm facilitation in Aplysia. Neuron. 2008;59(6):1024-36. doi: 10.1016/j.neuron.2008.07.036. PubMed PMID: 18817739; PubMed Central PMCID: PMCPMC3442368. 
29. Si K, Choi YB, White-Grindley E, Majumdar A, Kandel ER. Aplysia CPEB can form prion-like multimers in sensory neurons that contribute to long-term facilitation. Cell. 2010;140(3):421-35. doi: 10.1016/j.cell.2010.01.008. PubMed PMID: 20144764.

30. Majumdar A, Cesario WC, White-Grindley E, Jiang H, Ren F, Khan MR, et al. Critical role of amyloid-like oligomers of Drosophila Orb2 in the persistence of memory. Cell. 2012;148(3):515-29. doi: 10.1016/j.cell.2012.01.004. PubMed PMID: 22284910.

31. Fioriti L, Myers C, Huang YY, Li X, Stephan JS, Trifilieff P, et al. The Persistence of Hippocampal-Based Memory Requires Protein Synthesis Mediated by the Prion-like Protein CPEB3. Neuron. 2015;86(6):1433-48. doi: 10.1016/j.neuron.2015.05.021. PubMed PMID: 26074003.

32. Hervas R, Li LY, Majumdar A, Fernandez-Ramirez MD, Unruh JR, Slaughter BD, et al. Molecular Basis of Orb2 Amyloidogenesis and Blockade of Memory Consolidation. Plos Biology. 2016;14(1). doi: ARTN e1002361 10.1371/journal.pbio.1002361. PubMed PMID: WOS:000371882900026.

33. Rayman JB, Kandel ER. Functional Prions in the Brain. Cold Spring Harb Perspect Biol. 2017;9(1). doi: 10.1101/cshperspect.a023671. PubMed PMID: 28049644; PubMed Central PMCID: PMCPMC5204323.

34. Hervas R, Rau MJ, Park Y, Zhang W, Murzin AG, Fitzpatrick JAJ, et al. Cryo-EM structure of a neuronal functional amyloid implicated in memory persistence in Drosophila. Science. 2020;367(6483):1230-4. doi: 10.1126/science.aba3526. PubMed PMID: 32165583; PubMed Central PMCID: PMCPMC7182444.

35. Keleman K, Kruttner S, Alenius M, Dickson BJ. Function of the Drosophila CPEB protein Orb2 in long-term courtship memory. Nat Neurosci. 2007;10(12):1587-93. doi: 10.1038/nn1996. PubMed PMID: 17965711.

36. Drisaldi B, Colnaghi L, Fioriti L, Rao N, Myers C, Snyder AM, et al. SUMOylation Is an Inhibitory Constraint that Regulates the Prion-like Aggregation and Activity of CPEB3. Cell Rep. 2015;11(11):1694-702. doi: 10.1016/j.celrep.2015.04.061. PubMed PMID: 26074071.

37. Stephan JS, Fioriti L, Lamba N, Colnaghi L, Karl K, Derkatch IL, et al. The CPEB3 Protein Is a Functional Prion that Interacts with the Actin Cytoskeleton. Cell Rep. 2015;11(11):1772-85. doi: 10.1016/j.celrep.2015.04.060. PubMed PMID: 26074072.

38. Gu XY, Schafer NP, Wang Q, Song SS, Chen MC, Waxham MN, et al. Exploring the Factin/CPEB3 interaction and its possible role in the molecular mechanism of long-term memory. P Natl Acad Sci USA. 2020;117(36):22128-34. doi: 10.1073/pnas.2012964117. PubMed PMID: WOS:000572964500015.

39. Chao HW, Tsai LY, Lu YL, Lin PY, Huang WH, Chou HJ, et al. Deletion of CPEB3 enhances hippocampus-dependent memory via increasing expressions of PSD95 and NMDA receptors. J Neurosci. 2013;33(43):17008-22. doi: 10.1523/JNEUROSCI.3043-13.2013. PubMed PMID: 24155305.

40. Fong N, Ohman M, Bentley DL. Fast ribozyme cleavage releases transcripts from RNA polymerase II and aborts co-transcriptional pre-mRNA processing. Nat Struct Mol Biol. 2009;16(9):916-22. doi: 10.1038/nsmb.1652. PubMed PMID: 19701200; PubMed Central PMCID: PMCPMC2755206.

41. Chadalavada DM, Gratton EA, Bevilacqua PC. The human HDV-like CPEB3 ribozyme is intrinsically fast-reacting. Biochemistry-Us. 2010;49(25):5321-30. doi: 10.1021/bi100434c. PubMed PMID: 20524672; PubMed Central PMCID: PMCPMC2890282.

42. Singh J, Padgett RA. Rates of in situ transcription and splicing in large human genes. Nat Struct Mol Biol. 2009;16(11):1128-33. doi: 10.1038/nsmb.1666. PubMed PMID: 19820712; PubMed Central PMCID: PMCPMC2783620. 
43. Neves G, Cooke SF, Bliss TV. Synaptic plasticity, memory and the hippocampus: a neural network approach to causality. Nat Rev Neurosci. 2008;9(1):65-75. doi: 10.1038/nrn2303. PubMed PMID: 18094707.

44. Harris DA, Tinsley RA, Walter NG. Terbium-mediated footprinting probes a catalytic conformational switch in the antigenomic hepatitis delta virus ribozyme. J Mol Biol. 2004;341(2):389-403. doi: 10.1016/j.jmb.2004.05.074. PubMed PMID: 15276831.

45. Hua Y, Sahashi K, Hung G, Rigo F, Passini MA, Bennett CF, et al. Antisense correction of SMN2 splicing in the CNS rescues necrosis in a type III SMA mouse model. Genes Dev. 2010;24(15):1634-44. doi: 10.1101/gad.1941310. PubMed PMID: 20624852; PubMed Central PMCID: PMCPMC2912561.

46. Du L, Richter JD. Activity-dependent polyadenylation in neurons. RNA. 2005;11(9):1340-7. doi: 10.1261/rna.2870505. PubMed PMID: 16043499; PubMed Central PMCID: PMCPMC1370817.

47. Pavlopoulos E, Trifilieff P, Chevaleyre V, Fioriti L, Zairis S, Pagano A, et al. Neuralized1 activates CPEB3: a function for nonproteolytic ubiquitin in synaptic plasticity and memory storage. Cell. 2011;147(6):1369-83. doi: 10.1016/j.cell.2011.09.056. PubMed PMID: 22153079; PubMed Central PMCID: PMCPMC3442370.

48. Chao HW, Lai YT, Lu YL, Lin CL, Mai W, Huang YS. NMDAR signaling facilitates the IPO5mediated nuclear import of CPEB3. Nucleic Acids Res. 2012;40(17):8484-98. doi: 10.1093/nar/gks598. PubMed PMID: 22730302; PubMed Central PMCID: PMCPMC3458550.

49. Vogel-Ciernia A, Wood MA. Examining object location and object recognition memory in mice. Curr Protoc Neurosci. 2014;69:8 31 1-17. doi: 10.1002/0471142301.ns0831s69. PubMed PMID: 25297693; PubMed Central PMCID: PMCPMC4219523.

50. Kandel ER. The molecular biology of memory storage: a dialogue between genes and synapses. Science. 2001;294(5544):1030-8. doi: 10.1126/science.1067020. PubMed PMID: 11691980.

51. Frey U, Morris RGM. Synaptic tagging and long-term potentiation. Nature. 1997;385(6616):533-6. doi: DOI 10.1038/385533a0. PubMed PMID: WOS:A1997WG23500047.

52. Richter JD. Translational control of synaptic plasticity. Biochem Soc T. 2010;38:1527-30. doi: 10.1042/Bst0381527. PubMed PMID: WOS:000285813100024.

53. Neugebauer KM. Nascent RNA and the Coordination of Splicing with Transcription. Csh Perspect Biol. 2019;11(8). doi: ARTN a032227 10.1101/cshperspect.a032227. PubMed PMID: WOS:000482756900001.

54. Reimer KA, Mimoso CA, Adelman K, Neugebauer KM. Co-transcriptional splicing regulates 3' end cleavage during mammalian erythropoiesis. Molecular Cell. 2021. doi: https://doi.org/10.1016/j.molcel.2020.12.018.

55. Diering GH, Huganir RL. The AMPA Receptor Code of Synaptic Plasticity. Neuron. 2018;100(2):314-29. doi: 10.1016/j.neuron.2018.10.018. PubMed PMID: 30359599; PubMed Central PMCID: PMCPMC6214363.

56. Si K, Kandel ER. The Role of Functional Prion-Like Proteins in the Persistence of Memory. Cold Spring Harb Perspect Biol. 2016;8(4):a021774. doi: 10.1101/cshperspect.a021774. PubMed PMID: 27037416; PubMed Central PMCID: PMCPMC4817803.

57. Seth PP, Siwkowski A, Allerson CR, Vasquez G, Lee S, Prakash TP, et al. Short antisense oligonucleotides with novel 2'-4' conformationaly restricted nucleoside analogues show improved potency without increased toxicity in animals. J Med Chem. 2009;52(1):10-3. doi: 10.1021/jm801294h. PubMed PMID: 19086780.

58. Wirths O. Preparation of Crude Synaptosomal Fractions from Mouse Brains and Spinal Cords. Bio-Protocol. 2017;7(15). doi: ARTN e2423 10.21769/BioProtoc.2423. PubMed PMID: WOS:000457836100005. 
701

702

703

704

705

706

707

708

709

710

711

712

713

714

715

716

717

718

719

720

721

722

723

724

725

726

727

728

729

730

731

\section{Acknowledgments}

We thank M. Malgowska, C-K. Lau, and M. A. Sta Maria for experimental assistance.

Funding:

National Institutes of Health grant R01AG051807 (MAW)

National Institutes of Health grant RF1AG057558 (MAW)

National Science Foundation 1804220 (AL)

National Science Foundation 1330606 (AL)

National Science Foundation Graduate Research Fellowship (CCC)

\section{Author contributions:}

Design of cell culture experiments: CCC, XL, TWB, AL

Design of mouse experiments: CCC, MAW, AL

In vitro ribozyme kinetics measurements: MM

Design of ASOs: MN

Cell culture experiments: CCC, LT, XL

Mouse experiments: CCC

Stereotaxic surgeries and in vivo behavior experiments: JH, CC

Data analysis: CCC

Writing - original draft: $\mathrm{CCC}, \mathrm{AL}$

Writing — review \& editing: CCC, MN, XL, LT, TWB, MAW, AL

Competing interests: All other authors declare they have no competing interests.

Data and materials availability: All data are available in the main text or the supplementary materials. 
Figures and Tables

A mCPEB3
gene

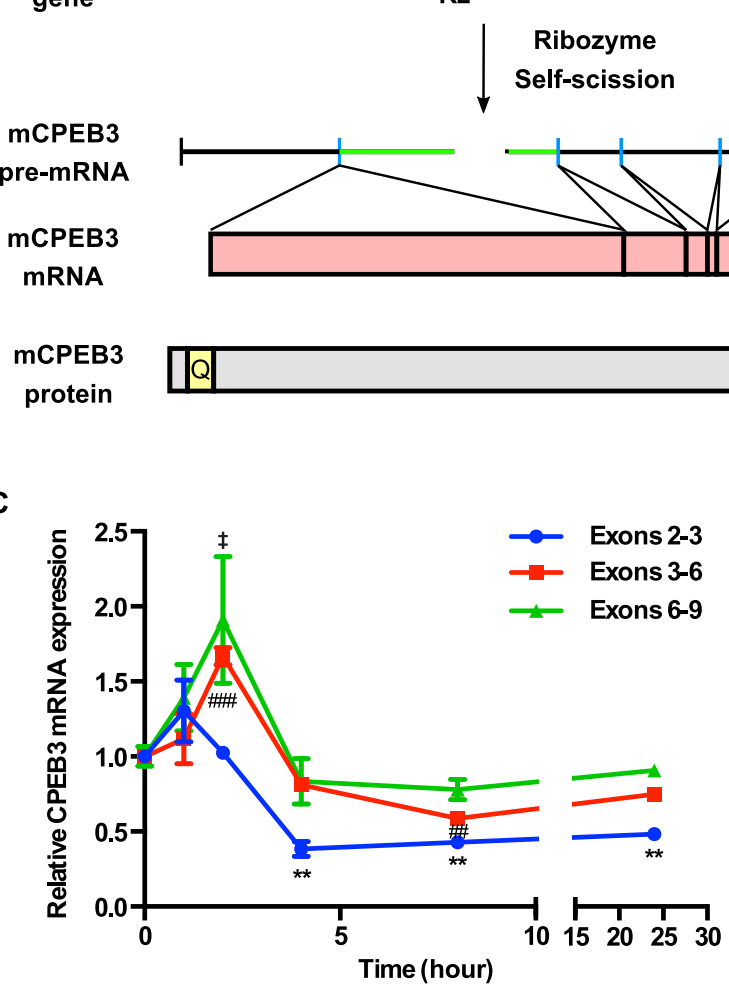

E

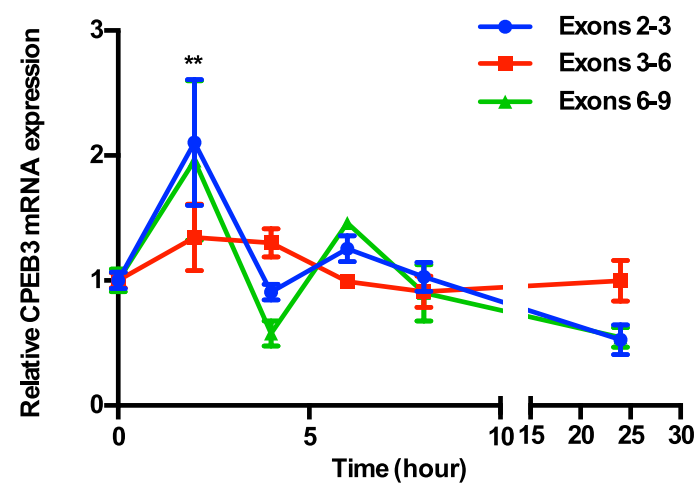

D

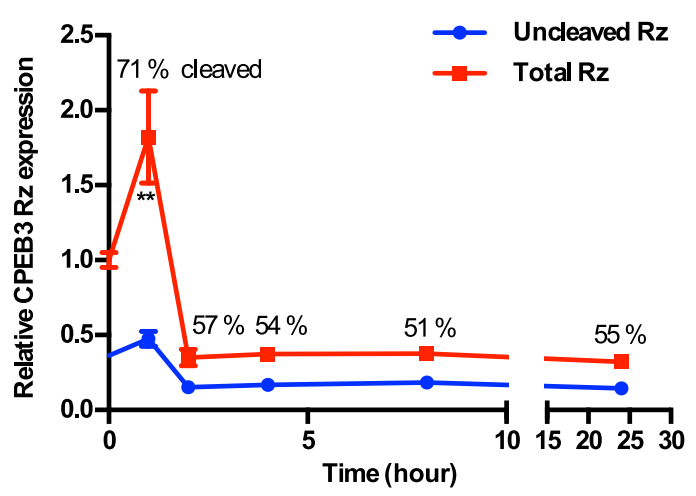

F

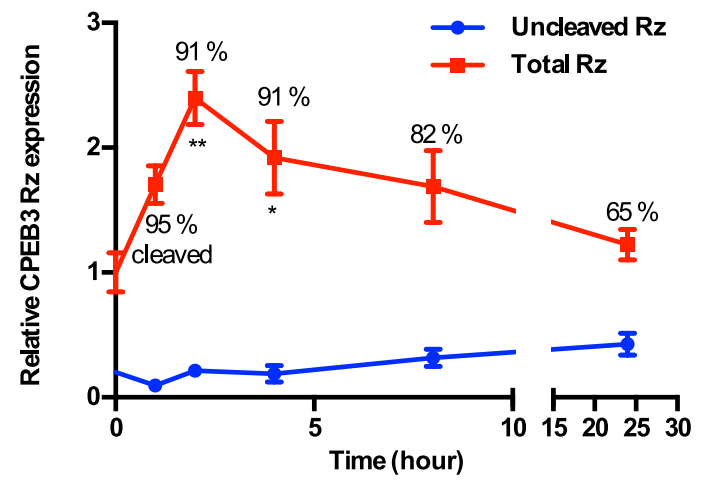

Fig 1. CPEB3 ribozyme activity and its effect on primary cortical neurons. (A) Schematic representation of mouse $C P E B 3$ gene and its products. $\mathrm{Rz}$ denotes the ribozyme location in the $2^{\text {nd }}$ intron (green) between the $2^{\text {nd }}$ and $3^{\text {rd }}$ exons. Co-transcriptional self-scission is shown by a break in the pre-mRNA $2^{\text {nd }}$ intron. Fully-spliced mRNA is shown independent of the ribozyme activity. (B) Co-transcriptional self-cleavage activity of a 470-nt construct, incorporating the 72-nt ribozyme, which cuts the transcript $233 \mathrm{nts}$ from the $5^{\prime}$ terminus (see Table S1 for kinetic parameters of this and other constructs). Log-linear graph of self- 
cleavage is shown with solid blue line (dashed lines show \pm standard deviation). Gray dotted line indicates mid-point of self-cleavage (with resulting $\mathrm{t}_{1 / 2}$ of $\sim 2 \mathrm{~min}$ ). Gray bar indicates the approximate time range for RNAPII to reach from the ribozyme to the $3^{\text {rd }}$ exon, at which

point $\sim 40 \%$ of the intron would remain intact. (C) $\mathrm{KCl}$ stimulation profile of the $C P E B 3$ gene showing induction of spliced CPEB3 exons (one-way ANOVA with Sidak's post hoc tests. $* P<0.05, * * P<0.01, \# \# P<0.01, \# \# \# P<0.001, \sharp P<0.05)$. (D) $\mathrm{KCl}$ stimulation profile of CPEB3 ribozyme expression (uncleaved and total). Cleaved ribozyme fraction is calculated as [(total ribozyme - uncleaved ribozyme)/total ribozyme] and shown as \% cleaved. (E) Expression of CPEB3 mRNA exons 2-3 is upregulated 2 hours after glutamate stimulation (one-way ANOVA with Sidak's multiple comparisons post hoc test. ${ }^{* *} P<0.01$ ). (F) Glutamate stimulation induces an increase in CPEB3 ribozyme levels at 2-hour time point (one-way ANOVA with Sidak's multiple comparisons post hoc test. ${ }^{*} P<0.05, * * P<0.01$ ). Data are presented as mean \pm SEM. 
A

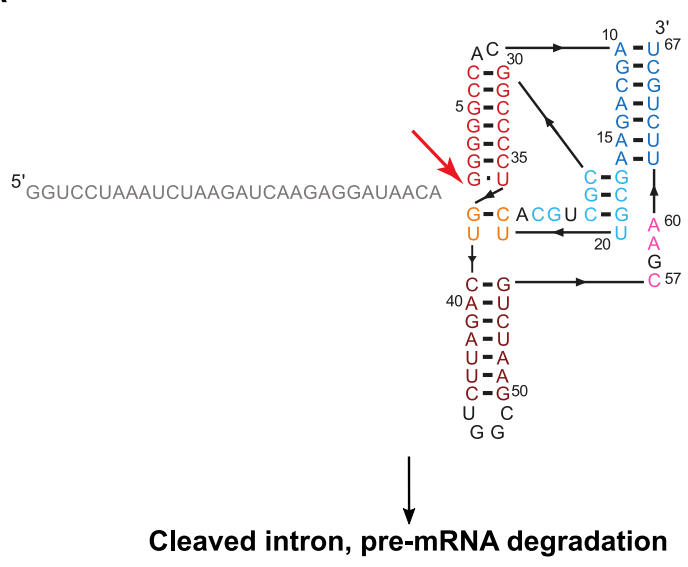

C

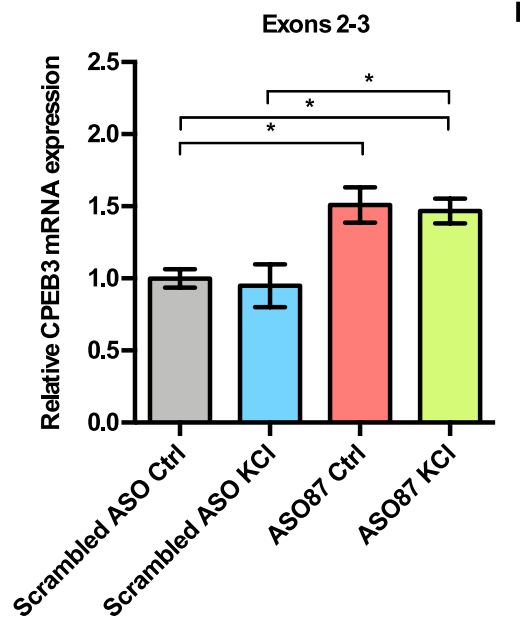

D
B

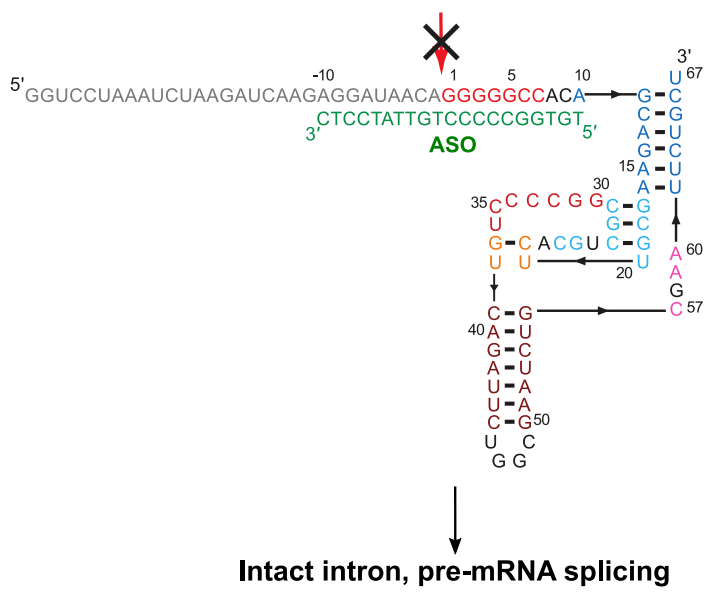

CPEB3

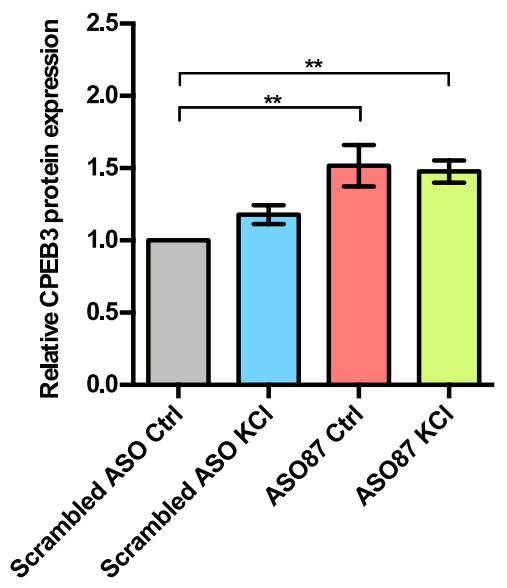

CPEB3

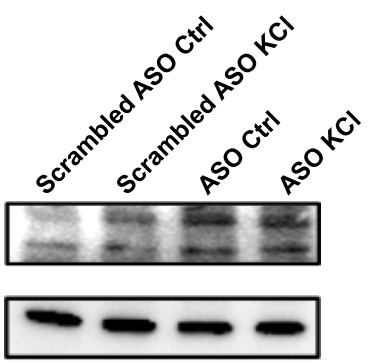

Fig 2. CPEB3 mRNA and protein are upregulated in primary neuronal cultures treated

with ASO. (A) Inhibition of the CPEB3 ribozyme by an ASO targeting its cleavage site. Secondary structure of the ribozyme (colored by structural elements [10]). Sequence upstream of the ribozyme is shown in gray, and the site of self-scission is shown with the red arrow. (B) Model of the ribozyme inhibited by the antisense oligonucleotide (ASO, green letters) showing base-pairing between the ASO and 10 nts upstream and downstream of the ribozyme cleavage site. Inhibition of self-scission is indicated by crossed arrow. (C) Ribozyme inhibition by ASO in cultured cortical neurons resulted in upregulation of CPEB3 mRNA (exons 2-3; one-way ANOVA with Sidak's post hoc tests, ${ }^{*} P<0.05$ ). (D) Effect of CPEB3 ribozyme ASO on CPEB3 protein expression. GAPDH is used as a loading control (one-way 
bioRxiv preprint doi: https://doi.org/10.1101/2021.01.23.426448; this version posted May 5, 2021. The copyright holder for this preprint (which was not certified by peer review) is the author/funder, who has granted bioRxiv a license to display the preprint in perpetuity. It is made available under aCC-BY-NC-ND 4.0 International license.

ANOVA with Sidak's post hoc tests, $\left.{ }^{*} P<0.05,{ }^{* *} P<0.01\right)$. Data are presented as mean \pm

SEM. 
A

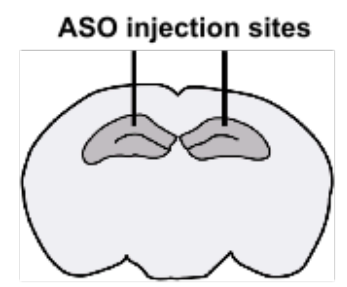

B

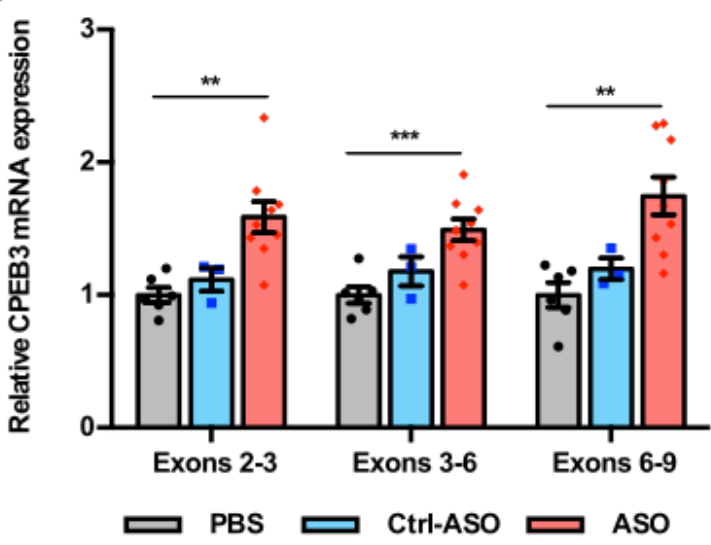

C

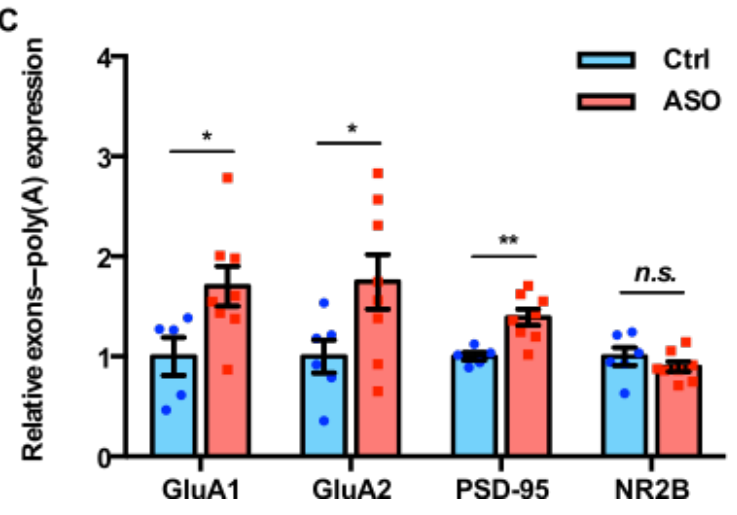

Fig 3. CPEB3 ribozyme ASO leads to an increase of CPEB3 mRNA and polyadenylation

of PRPs in the CA1 hippocampus. (A) Schematic representation of stereotaxic procedure.

CPEB3 mRNA expression is upregulated in the CPEB3 ribozyme ASO treatment group compared to controls (one-way ANOVA with Sidak's post hoc tests. $* * P<0.01, * * * P<$ 0.001). (C) Inhibition of CPEB3 ribozyme results in increased polyadenylation of plasticityrelated genes (unpaired $t$ test, ${ }^{*} P<0.05, * * P<0.01$, n.s. not significant). Data are presented as mean \pm SEM. 
A

Training

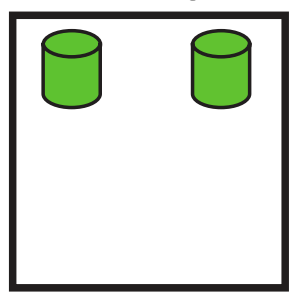

10 minutes
Testing

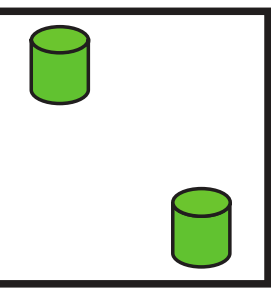

5 minutes

B

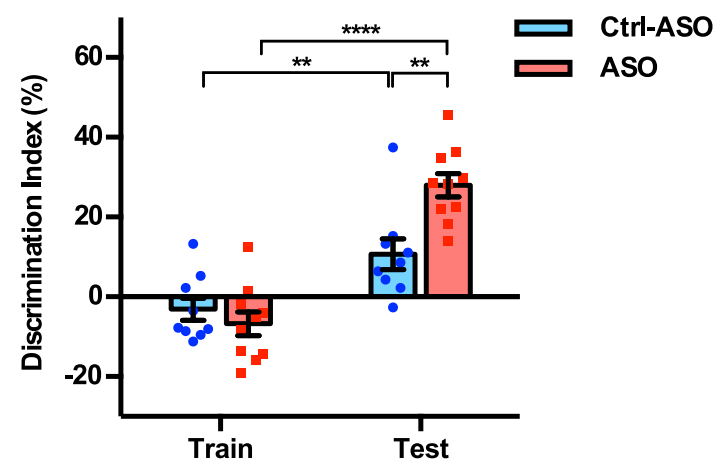

C

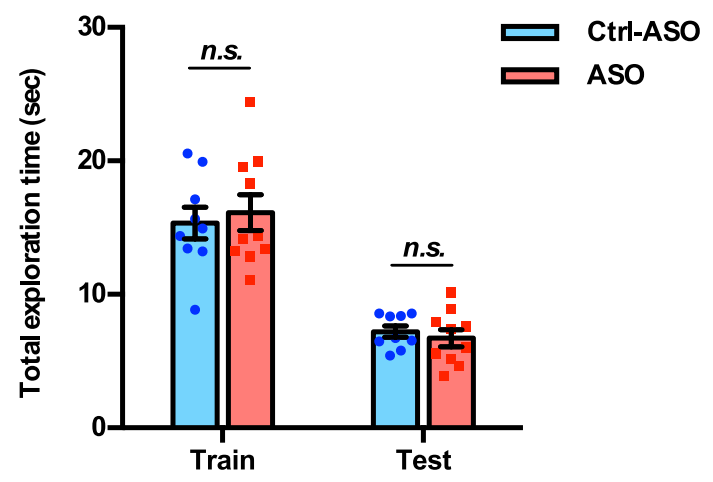

Fig 4. Inhibition of CPEB3 ribozyme enhances long-term OLM. (A) Experimental

procedure testing long-term memory. (B) Mice infused with CPEB3 ribozyme ASO show significant discrimination index in OLM testing (two-way ANOVA with Sidak's post hoc tests, $* P<0.05, * * P<0.01, * * * * P<0.0001$ ). (C) CPEB3 ribozyme ASO and control mice display similar total exploration time (one-way ANOVA with Sidak's post hoc tests, n.s. not significant). Data are presented as mean \pm SEM. 


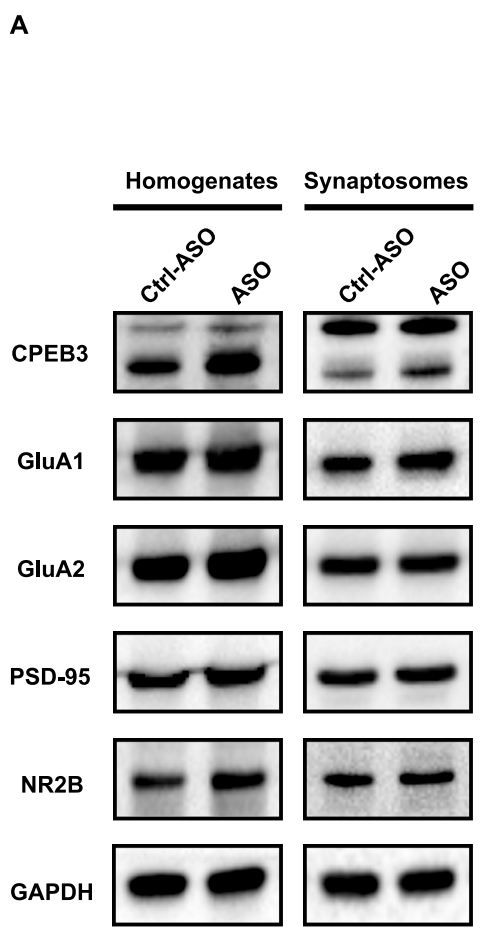

B

Homogenates

CPEB3

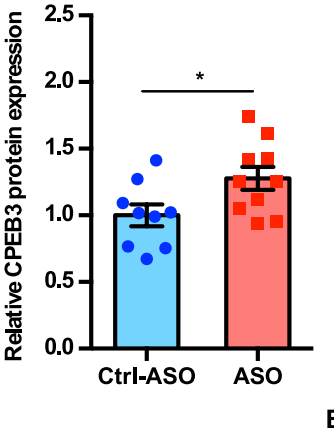

Synaptosomes

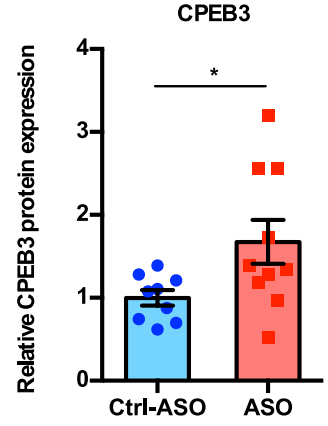

C

Homogenates

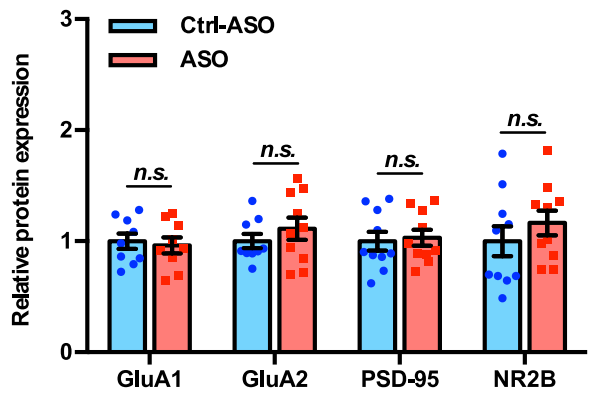

E

Synaptosomes

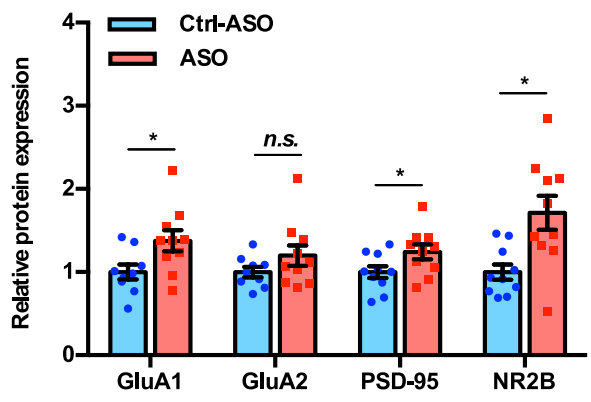

Fig 5. Inhibition of CPEB3 ribozyme leads to upregulation of CPEB3 and PRPs protein expression after OLM. (A) Representative images of immunoblotting analysis. GAPDH is used as a loading control. Quantification of CPEB3 (B) and PRPs (C) in tissue homogenates shows increased CPEB3, but not PRPs, protein expression (unpaired $t$ test, $* P<0.05$, n.s. not significant). (D) In synaptosomes, the protein expression of both CPEB3 (D) and PRPs (E) is increased (unpaired $t$ test, ${ }^{*} P<0.05$, n.s. not significant). Data are presented as mean \pm SEM. 
bioRxiv preprint doi: https://doi.org/10.1101/2021.01.23.426448; this version posted May 5, 2021. The copyright holder for this preprint (which

was not certified by peer review) is the author/funder, who has granted bioRxiv a license to display the preprint in perpetuity. It is made available under aCC-BY-NC-ND 4.0 International license.

801

802

803

804

805

806

807

808

809

810

811

812

813

814

815

816

817

818

819

820

821

822

823

824

825

826

827

828

829

\section{Supplementary Materials for The CPEB3 ribozyme modulates hippocampal-dependent memory}

Claire C. Chen, Joseph Han, Carlene A. Chinn, Xiang Li, Mehran Nikan, Marie Myszka, Liqi Tong, Timothy W. Bredy, Marcelo A. Wood*, Andrej Lupták*

*Corresponding author. Email: aluptak@uci.edu

mwood@uci.edu

This PDF file includes:

Figs S1 to S5

Tables S1 to S4 

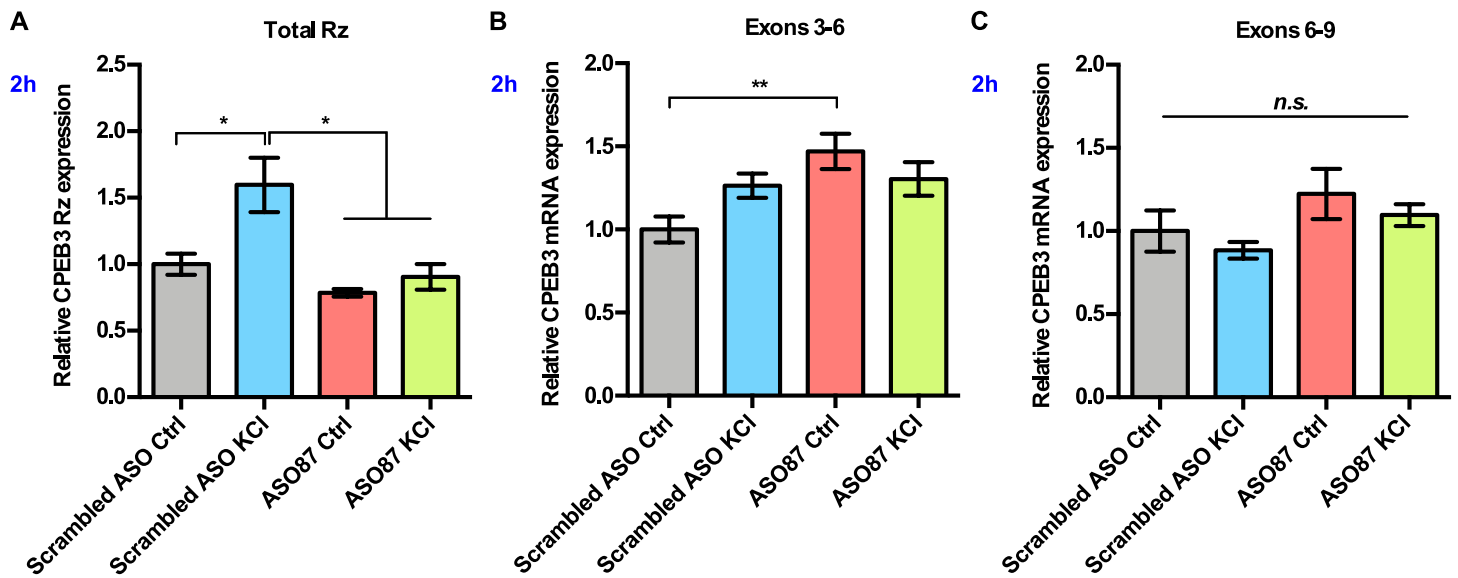

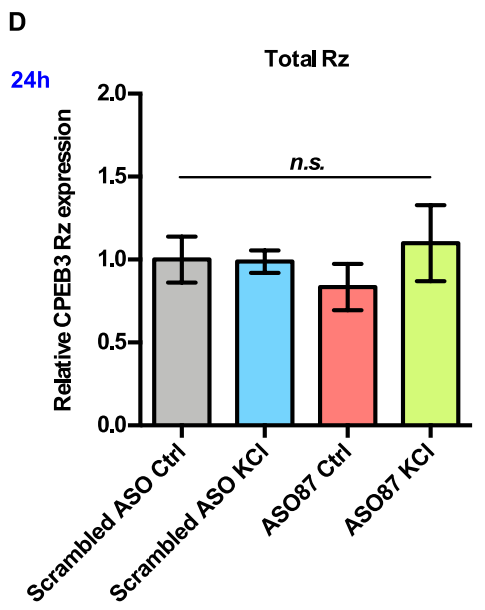

E

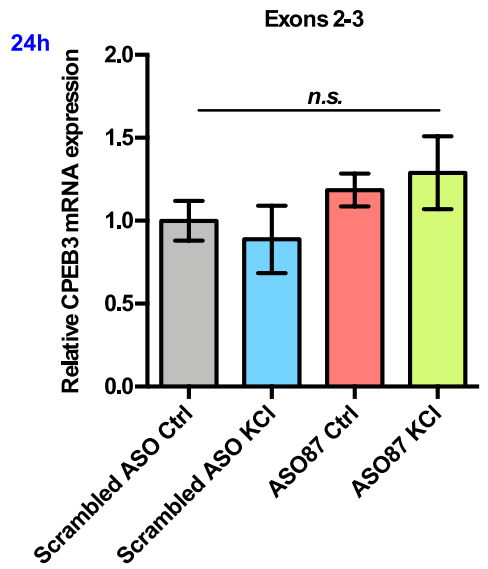

H

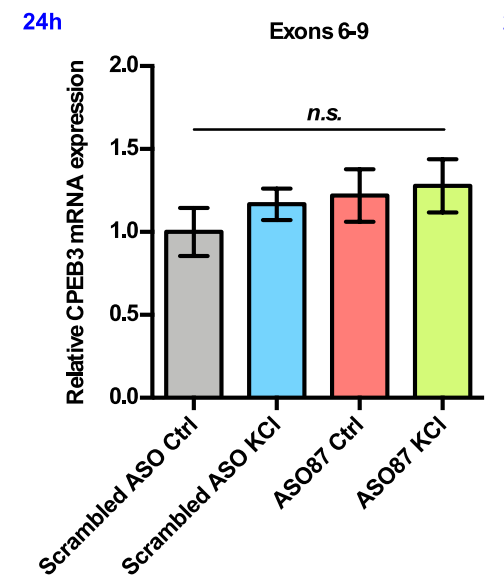

$2 \mathrm{~h}$

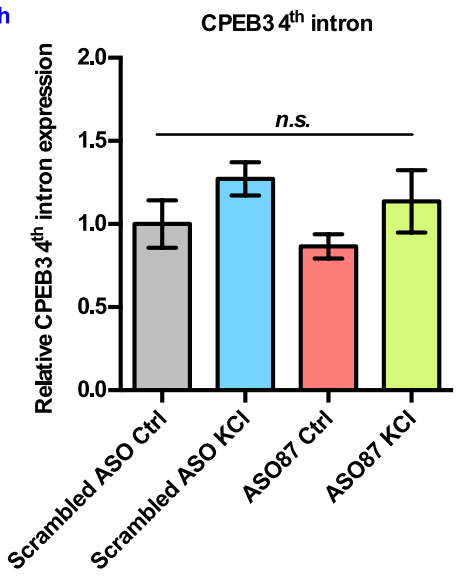

$\mathbf{F}$

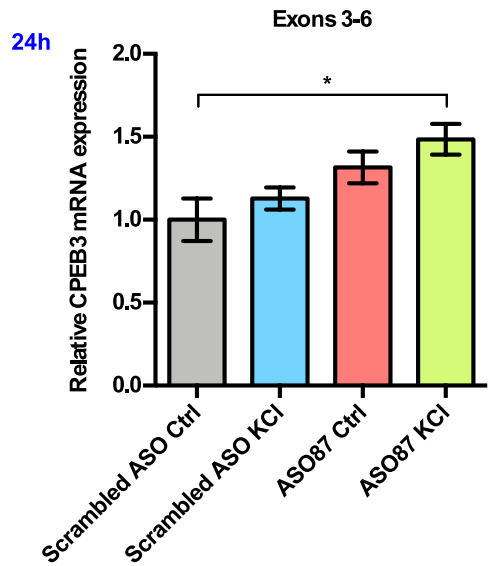

neurons. (A) CPEB3 ribozyme levels increase together with levels of the surrounding exons 
lower in ribozyme ASO experiments, suggesting blocking of the RT-PCR reaction by the ASO. (B) and (C) Inhibition of CPEB3 ribozyme by ASO resulted in upregulation of CPEB3 mRNA basal levels for exons 3-6 (B) at 2-hour time point. Levels of exons 6-9 did not increase significantly (C) (one-way ANOVA with Sidak's post hoc tests, $* * P<0.01$, n.s. not significant). (D) No statistically significant difference in CPEB3 ribozyme expression was observed after 24 hours post $\mathrm{KCl}$ induction (one-way ANOVA with Sidak's post hoc tests, n.s. not significant), suggesting that all intronic RNA levels reached basal levels. (E) - (G) CPEB3 mRNA expression largely returned to the basal level 24 hours post stimulation, although levels of spliced exons 3-6 remained elevated (E: exons 2-3, F: exons 3-6, G: exons 6-9, one-way ANOVA with Sidak's post hoc tests, ${ }^{*} P<0.05$, n.s. not significant). (H) qRTPCR analysis of CPEB3 $4^{\text {th }}$ intron expression reveals that the ribozyme ASO does not affect its levels, suggesting that it is specific for the ribozyme (one-way ANOVA with Sidak's post hoc tests, n.s. not significant). (I) Effect of ASOs treatment on cell viability. XTT assay was performed after 18 hours incubation of ASOs. Relative cell viability was normalized to the vehicle control (unpaired $t$ test, $n . s$. not significant). Data are presented as mean $\pm \mathrm{SEM}$. 
A

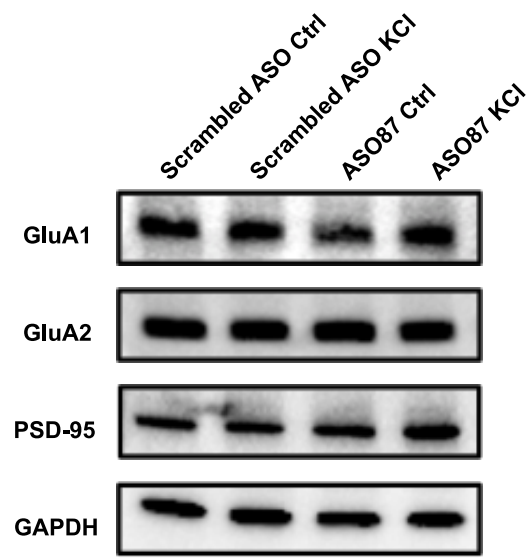

c

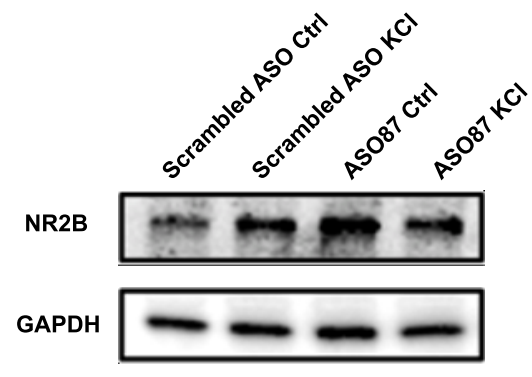

B

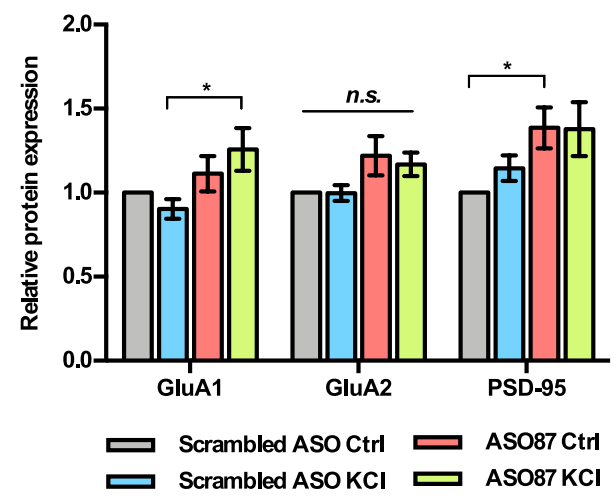

D

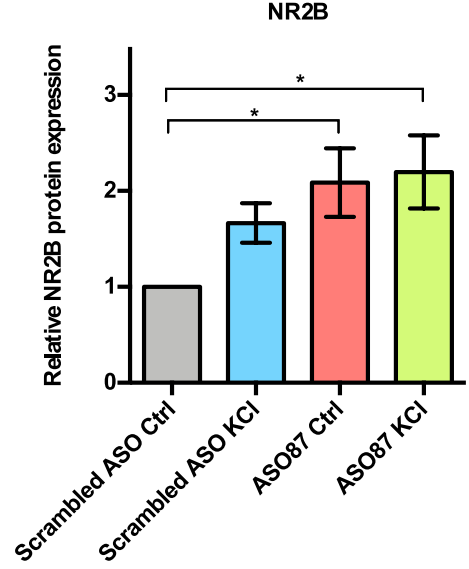

\section{S2 Fig. Effect of CPEB3 ribozyme ASO on protein expression in embryonic cortical}

neurons. Primary neuronal cultures were pretreated with ASO or scrambled ASO, followed by $\mathrm{KCl}$ stimulation. Cells were harvested 8 hours after $\mathrm{KCl}$ induction. PRPs protein 
864 expression (one-way ANOVA with Sidak's post hoc tests. ${ }^{*} P<0.05$ ). Data are presented as 865 mean \pm SEM. The analysis revealed that the steady-state levels of GluA1 are elevated when 866 the CPEB3 ribozyme is inhibited, but these levels do not increase further upon $\mathrm{KCl}$ 867 stimulation of the cultured cortical neurons. 
A

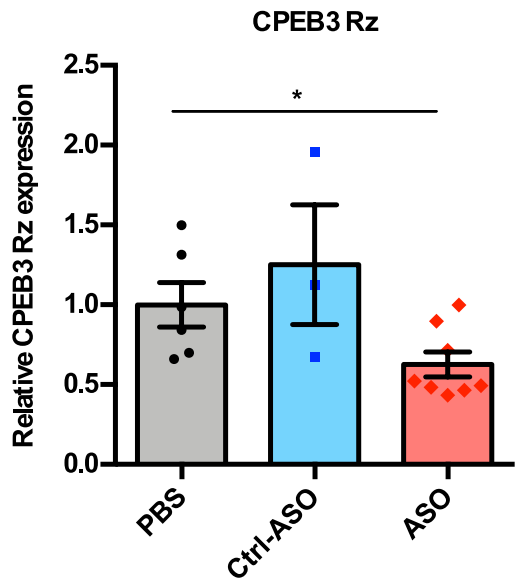

B

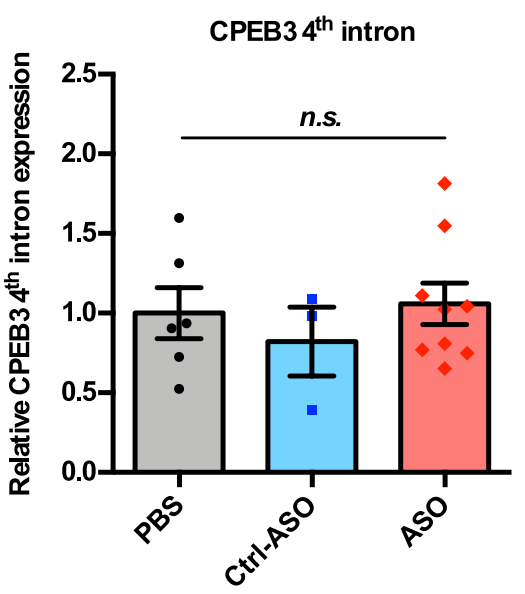

S3 Fig. Inhibition of CPEB3 ribozyme by ASO in vivo. (A) Validation of CPEB3 ribozyme knockdown in vivo. Administration of CPEB3 ribozyme ASO to the mouse CA1 hippocampus leads to a decrease in CPEB3 ribozyme levels (one-way ANOVA with Sidak's post hoc tests $* P<0.05$ ). (B) The ribozyme ASO has high specificity for its cleavage site (in the $3^{\text {rd }}$ intron) in vivo. qRT-PCR analysis of the $4^{\text {th }}$ intron of CPEB3 gene demonstrates no significant difference between controls and ASO groups (one-way ANOVA with Sidak's post hoc test, n.s. not significant). Data are presented as mean \pm SEM. 


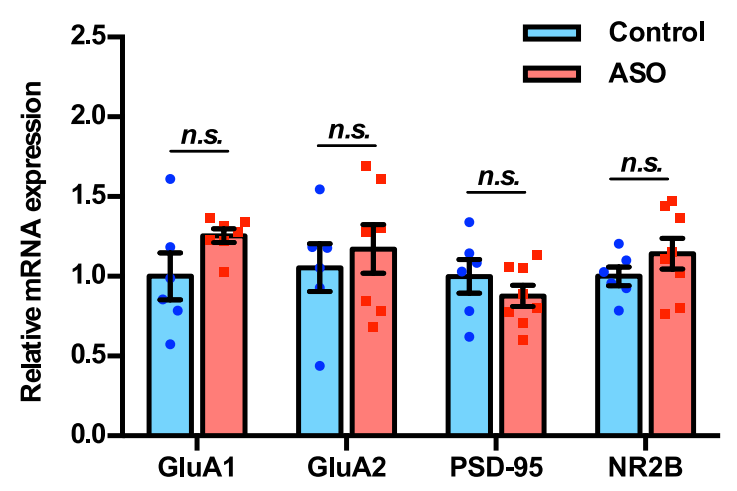

S4 Fig. Inhibition of CPEB3 ribozyme does not affect transcription of other plasticityrelated genes. qRT-PCR analysis of mature GluA1, GluA2, PSD-95, and NR2B mRNAs. No significant difference between ASO and control was observed for splice junctions within the mRNAs, showing that modulation of the CPEB3 ribozyme does not affect transcription or splicing of these mRNAs (unpaired $t$ test, n.s. not significant). Data are presented as mean \pm SEM. 
A
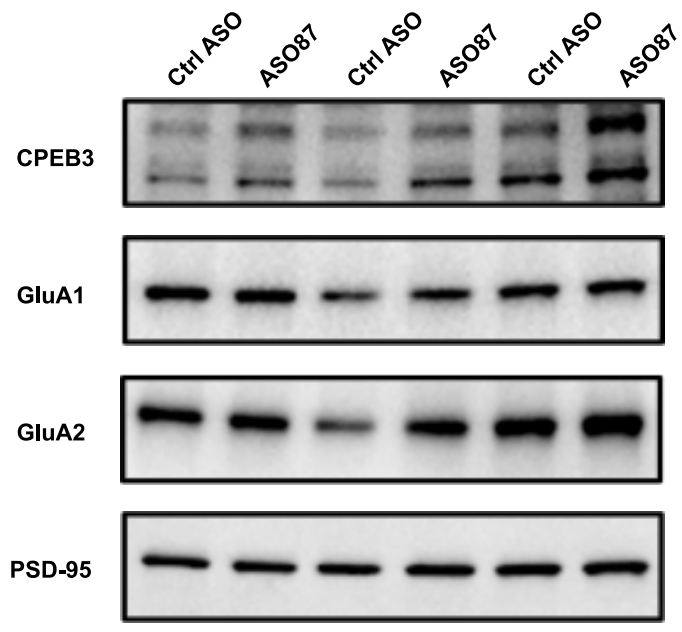

NR2B

GAPDH

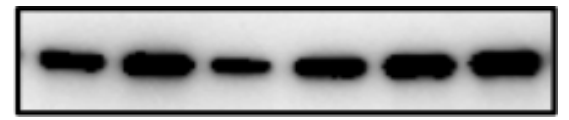

B

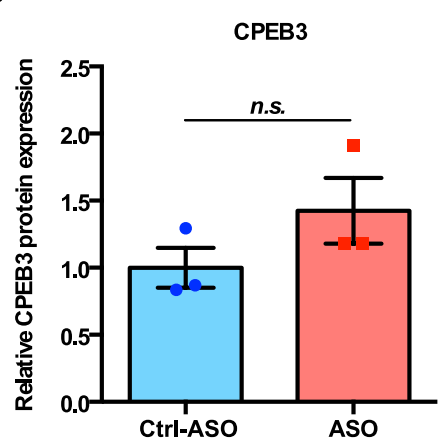

C

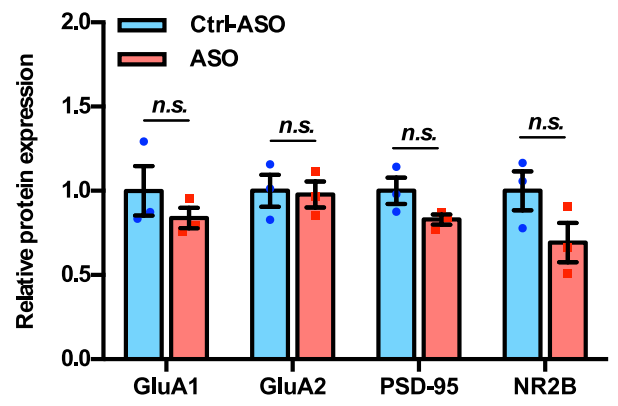

hippocampus. (A) Representative images of immunoblotting analysis. GAPDH is used as a significant). Data are presented as mean $\pm \mathrm{SEM}$. 
S1 Table. Kinetic parameters of murine CPEB3 ribozyme constructs ${ }^{2}$

\begin{tabular}{|c|c|c|c|c|c|}
\hline Construct $^{1}$ & $\mathbf{A}$ & $\boldsymbol{k}_{\mathbf{1}}$ & $\mathbf{B}$ & $\boldsymbol{k}_{\mathbf{2}}$ & $\mathbf{C}$ \\
\hline$-10 / 72$ & $0.72 \pm 0.09$ & $0.39 \pm 0.09$ & & & $0.082 \pm 0.026$ \\
\hline$-49 / 72 / 165$ & $0.88 \pm 0.02$ & $0.42 \pm 0.04$ & $0.013 \pm 0.015$ & $0.11 \pm 0.03$ & $0.04 \pm 0.02$ \\
\hline$-233 / 72 / 165$ & $0.78 \pm 0.04$ & $0.31 \pm 0.04$ & $0.035 \pm 0.006$ & $0.17 \pm 0.02$ & $0.029 \pm 0.005$ \\
\hline
\end{tabular}

${ }^{1}$ Construct size is defined as the length of sequence upstream of the ribozyme cleavage site/CPEB3 ribozyme (72 nts)/downstream sequence.

${ }^{2}$ Co-transcriptional self-scission was modeled by a bi-exponential decay model with a residual. $\mathrm{A}$ and $\mathrm{B}$ represent fractions of the population cleaving with fast $\left(k_{1}\right)$ and slow $\left(k_{2}\right)$ rate constants, respectively. The residual $(\mathrm{C})$ is interpreted as a fraction of the population that does not self$(-10 / 72)$, a monoexponential decay function was sufficient to model the data. 
S2 Table. Primers used in qPCR

\begin{tabular}{|c|c|c|}
\hline Target & & Sequence \\
\hline \multirow{2}{*}{ CPEB3 exons $2-3$} & Forward & CGATAATGGTAACAATCTGTTGCC \\
\hline & Reverse & ССТTATCATATCCATTAAGGAGTTCTCC \\
\hline \multirow{2}{*}{ CPEB3 exons 3-6 } & Forward & GACCGGAGTAGGCCCTATGA \\
\hline & Reverse & CCAGACGATAAGGCCTGATCA \\
\hline \multirow{2}{*}{ CPEB3 exons 6-9 } & Forward & ACTCTAGAAAGGTGTTTGTTGGAGG \\
\hline & Reverse & TCGAAGGGGTCGTGGAACT \\
\hline \multirow{2}{*}{ CPEB3 ribozyme cleaved } & Forward & GTTCACGTCGCGGCC \\
\hline & Reverse & GTGATATAGTGTGTTCTTCAGTGACTCCT \\
\hline \multirow{2}{*}{ CPEB3 ribozyme uncleaved } & Forward & CCAAGCAGCAGCACAGGTC \\
\hline & Reverse & GTGATATAGTGTGTTCTTCAGTGACTCCT \\
\hline \multirow{2}{*}{ CPEB3 $4^{\text {th }}$ intron } & Forward & САСТСТAGCCTAACTGGTGAGCTC \\
\hline & Reverse & AGTCATTCCAACAGAAATGAAGTACC \\
\hline \multirow{2}{*}{ GluA1 } & Forward & GTCCGCCCTGAGAAATCCAG \\
\hline & Reverse & CTCGCCCTTGTCGTACCAC \\
\hline \multirow{2}{*}{ GluA2 } & Forward & TGGTACGACAAAGGAGAGTGC \\
\hline & Reverse & ACCAGCATTGCCAAACCAAG \\
\hline \multirow{2}{*}{ PSD-95 } & Forward & TGAGATCAGTCATAGCAGCTACT \\
\hline & Reverse & СТTССТССССТAGCAGGTCC \\
\hline \multirow{2}{*}{ NR2B } & Forward & GCCATGAACGAGACTGACCC \\
\hline & Reverse & GCTTCCTGGTCCGTGTCATC \\
\hline \multirow{2}{*}{ GAPDH } & Forward & TGACCACAGTCCATGCCATC \\
\hline & Reverse & GACGGACACATTGGGGGTAG \\
\hline
\end{tabular}




\section{S3 Table. Antibodies used in immunoblotting analysis}

\begin{tabular}{|c|c|c|c|c|}
\hline Antigen & Species & Company & Catalog \# & Dilution \\
\hline CPEB3 & Rabbit & Abcam & $75-327$ & $1: 1,000$ \\
\hline GluA1 & Mouse & $\begin{array}{c}\text { UC Davis/NIH NeuroMab } \\
\text { Facility }\end{array}$ & $1: 1,000$ \\
\hline GluA2 & Rabbit & Proteintech & $11994-1-A P$ & $1: 2,000$ \\
\hline PSD-95 & Rabbit & Proteintech & $20665-1-A P$ & $1: 2,000$ \\
\hline NR2B & Rabbit & Proteintech & $21920-1-A P$ & $1: 2,000$ \\
\hline GAPDH & Mouse & Proteintech & $60004-1-$ Ig & $1: 10,000$ \\
\hline Anti-rabbit HRP & Donkey & Thermo Fisher Scientific & A16023 & $1: 10,000$ \\
\hline Anti-mouse HRP & Goat & R\&D system & HAF007 & $1: 1,000$ \\
\hline
\end{tabular}

\section{S4 Table. Primers used in $3^{\prime}$ RACE}

\begin{tabular}{|c|l|}
\hline Target & \multicolumn{1}{|c|}{ Sequence } \\
\hline 3' RACE adaptor & $\begin{array}{l}\text { CCAGTGAGCAGAGTGACGAGGACTCGAGCTCAAGCTTTTTTTTTTTTTTTT } \\
\text { TTTT }\end{array}$ \\
\hline 3' RACE outer primer & CCAGTGAGCAGAGTGACG \\
\hline 3' RACE inner primer & GAGGACTCGAGCTCAAGC \\
\hline GluA1 & GGTCCGCCCTGAGAGGTCCC \\
\hline GluA1 nested & CCTGAGCAATGTGGCAGGCGT \\
\hline GluA2 & GCTACGGCATCGCCACACCT \\
\hline GluA2 nested & ATCCTTGTCGGGGGCCTTGGT \\
\hline PSD-95 & GGCCACGAAGCTGGAGCAGG \\
\hline PSD-95 nested & GGCCTGGACTCACCCTGCCT \\
\hline NR2B & GAGACGAAGGCTGCAAGCTGGT \\
\hline NR2B nested & CGCCAGGTGGACCTTGCTATCC \\
\hline
\end{tabular}

